Historia Slavorum Occidentis

2021, nr 3 (30)

ISSN 2084-1213

DOI: $10.15804 /$ hso210303

Maria Koczerska (WarszaWa)

ORCID: 0000-0002-2638-1388

\title{
Źródło - źródłoznawstwo - metoda w badaniach Aleksandra Gieysztora
}

Słowa kluczowe: historia historiografii, źródło historyczne, źródłoznawstwo, nauki pomocnicze historii, metodologia historii

Keywords: history of historiography, historical source, source studies, auxiliary sciences of history, methodology of history

Abstract: This paper describes how Aleksander Gieysztor consciously worked on mastering the research methods of history already during his studies; it presents the diversity of research issues he undertook and shows various types of historical sources (written, archaeological and folklore) that Gieysztor used in his work.

Nie pamiętam, aby Aleksander Gieysztor w którymkolwiek ze swych tekstów podał autorską definicję źródła historycznego. W świetle jego publikacji naukowych, jak również dydaktyki oglądanej przeze mnie przez lat przeszło trzydzieści - najpierw z perspektywy studentki, potem doktorantki, adiunkta hospitującego jego seminarium i współprowadzącej je - mogę tylko stwierdzić, że była to definicja najszersza z możliwych. Można by ją sformułować jednym zdaniem: źródłem historycznym jest wszystko to, z czego historyk może czerpać wiedzę o przeszłości.

Łatwiej określić pole badawcze - zakres zainteresowań i metody, jakie stosował. Była to najszerzej rozumiana historia społeczna, włączając w to historię kultury, ze świadomością społeczną na czele, stanowiącą jeden z najważniejszych jej komponentów. W jego bibliografii, odzwierciedlającej wielość i różnorodność pól badawczych, trudno znaleźć jakikolwiek temat, który można byłoby zakwalifikować do 
historii wydarzeniowej. Na pewno jego celem jako historyka nie była odpowiedź na pytanie sformulowane przez Leopolda Rankego: „Wie es engentlich gewesen?”. Zajmowały go bowiem zjawiska „długiego trwania”, czego najlepszym przykładem są dwa wątki, do których powracał w ciągu całej swej twórczości naukowej. Pierwszym wątkiem była recepcja chrześcijaństwa w Polsce - rozłożona, jak wiadomo, na wieki - a drugim - to, co było przedtem, a co zostało tylko częściowo wyparte przez nową religię, czyli mitologia pogańska. Z pewnością najbliższy mu był strukturalizm, propagowany przez francuską szkołę „Annales” Marca Blocha, Lucien Fabvre’a oraz Fernanda Braudela, kierującego przez kilkanaście lat (1956-1968) VI séction École Pratique des Hautes Études, której potem przewodził Jacques Le Goff.

Wśród metod badawczych w twórczości naukowej Aleksandra Gieysztora poczesne miejsce zajmowała metoda porównawcza, która dotyczyła zarówno terytorium - możliwie najszerszego - jak również analogicznych zjawisk i instytucji życia społecznego. Jak każdy mediewista musiał często, kiedy zawodziły źródła współczesne, stosować retrogresję. Najbardziej interesowały go problemy społeczne, ale widziane przez pryzmat jednostki, szczególnie dobrze wyrażającej epokę. Do takich w średniowieczu należeli święci z czasu i terytorium badanego, co nie powinno nas dziwić, bo miano świętych w chrześcijaństwie nadawano zawsze tym, którzy w sposób najdoskonalszy uosabiali ideały epoki. Postacią, do której A. Gieysztor szczególnie często się odwoływał, był św. Wojciech ${ }^{1}$ - patron wcześniejszego średniowiecza polskiego i czeskiego. A był on dla Gieysztora bohaterem różnych typów źródeł, do których sięgał: współcześnie pisanych żywotów; wyobrażeń plastycznych z epoki jak rzeźbiarskie przedstawienie na rzymskiej studzience na wyspie Tybrowej ${ }^{2}$, jak również ikonograficznych, ale z drugiej połowy XII w. - niemal komiksowe przedstawienie scen z życia świętego i historii jego relikwii w postaci płaskorzeźb Drzwi Gnieźnieńskich ${ }^{3}$. Oczywiście to ostatnie źródło, czerpiące z hagiografii, było dla Gieysztora i jego czytelników źródłem do poznania ideologii elity rządzącej czasów

1 Np. A. Gieysztor, Sanctus et gloriosissimus martyr Christi Adalbertus: un état et une église missionaire aux alentours de l'an mille, [w:] La conversione al cristianesimo nell'Europa dell'alto medioevo, Settimane di studio del Centro italiano di studi sull'alto medioevo, XIV: Spoleto, 14-20 aprile 1966, Spoleto 1967, s. 611-647.

2 Tenże, Rzymska studzienka ze św. Wojciechem z roku ok. 1000, [w:] Sztuka i historia. Księga pamiątkowa ku czci profesora Michata Walickiego, red. J. Białostocki, Warszawa 1966, s. 22-29.

3 Tenże, Problematyka ideologiczna Drzwi Gnieźnieńskich, Kwart. Hist. 62 (1955), s. 142-161; tenże, Drzwi Gnieźnieńskie jako wyraz polskiej świadomości narodowościowej w XII wieku, [w:] Drzwi Gnieźnieńskie, red. M. Walicki, t. I, Wrocław 1956, s. 1-19. 
Mieszka Starego - samego księcia, jego otoczenia świeckiego i dostojników Kościoła polskiego.

Do wykorzystywania różnorodnych źródeł był A. Gieysztor przygotowany jak mało kto i warto sobie zdać sprawę, że to przygotowanie warsztatowe w czasach studiów uniwersyteckich wydaje się być wynikiem jego własnego wyboru. Wiadomo bowiem, również z przekazanej mi przez prof. Jadwigę Karwasińską relacji, że Gieysztor już jako student pierwszego roku historii w 1933 r. poprosił ją o przyjęcie na zajęcia z nauk pomocniczych historii, mimo że były one przewidziane programem drugiego roku. Jako jedyny ze studentów uczęszczał w tymże roku akademickim 1933/1934 na wykład z dyplomatyki polskiej wieków średnich Stanisława Kętrzyńskiego ${ }^{4}$. Do anegdot Instytutu Historycznego Uniwersytetu Warszawskiego, przekazywanych z pokolenia na pokolenie, przeszło, że wykład ten tym różnił się pod względem formy od innych wykładów uniwersyteckich, że profesor Kętrzyński witał się z tym jedynym swoim słuchaczem przed rozpoczęciem wykładu i żegnał po jego zakończeniu - przez podanie ręki. Jako dodatkowe zajęcia student Gieysztor wybrał sobie jeszcze wykład z filologii klasycznej wraz z historią języka łacińskiego, prowadzony przez Adama Krokiewicza, oraz naukę paleografii głagolickiej i cyrylickiej, wykładanej przez Ivana Ohijenkę , późniejszego metropolitę prawosławnego Iłariona. Pamiętać również należy, że równolegle z historią studiował historię sztuki pod kierunkiem Zygmunta Batowskiego. Byłby prawdopodobnie ukończył i te studia, gdyby nie rozmowa z ówczesnym docentem Tadeuszem Manteufflem - uczniem Marcelego Handelsmana - który doradził mu skoncentrować się na tematyce tego seminarium, skoro wiadomości z historii sztuki i tak samodzielnie nabędzie, ale przy okazji - studiując historię̨ ${ }^{6}$.

Podczas studiów miał Aleksander Gieysztor jeszcze inne stałe zajęcia, najpierw w 1934 r. praktykę archiwalną w Archiwum Głównym Akt Dawnych, a następnie przez okres prawie dwuletni staż w tym miejscu, który nazywa swoim równoległym

4 Tenże, Nauki dające poznawać źródła historyczne w Uniwersytecie Warszawskim, [w:] Tradycje i perspektywy nauk pomocniczych historii $w$ Polsce. Materiaty $z$ sympozjum $w$ Uniwersytecie Jagiellońskim dnia 21-22 października 1993 profesorowi Zbigniewowi Perzanowskiemu przypisane, red. M. Rokosz, Kraków 1995, s. 31 n.; Nauka jako stużba. W 70-lecie urodzin i 50-lecie pracy naukowej profesora Aleksandra Gieysztora, wywiad przeprowadziła M. Koczerska, Kronika Warszawy 3/4 (1985), s. 131.

5 A. Gieysztor, Nauki dające poznawać, s. 31.

6 R. Jarocki, Opowieść o Aleksandrze Gieysztorze, Warszawa 2001, s. 276. 
uniwersytetem ${ }^{7}$. Archiwum to znajdowało się wówczas również przy ul. Długiej, ale nie pod numerem 7, jak obecnie, ale pod numerem 24. Gieysztor poznał tam źródła do historii Polski od czasów średniowiecznych do XIX w. włącznie, wykonując wszelkiego rodzaju prace archiwalne i ucząc się w ten sposób archiwistyki, ale również paleografii i struktury mazowieckich ksiąg sądowych od najlepszego ich znawcy i edytora Adama Wolffa. Muszę poczynić tu małą dygresję. Słuchałam tych wspomnień z przedwojennego Archiwum Głównego na uroczystej sesji z okazji 175-lecia AGAD-u w sali Balowej Pałacu Raczyńskich 7 XII 1983 r., gdy prof. Gieysztor był prezesem Polskiej Akademii Nauk, pierwszym wybranym demokratycznie w grudniu $1980 \mathrm{r}$. Zarówno ja, jak i wszyscy zebrani byli pod wrażeniem tego referatu, a wzruszenie autora wspominającego Archiwum z czasów młodości udzieliło się słuchaczom. Podziwialiśmy też wspaniałą pamięć prelegenta co do topografii archiwum i osób w nim pracujących. Gieysztor prowadził nas od drzwi wejściowych przez wszystkie pomieszczenia, zaczynając od gabinetu dyrektora, którym był wtedy Józef Siemieński - doskonały znawca dawnej Rzeczypospolitej, a równocześnie energiczny dyrektor tej arcyważnej instytucji kultury narodowej, który postanowił z niej stworzyć placówkę w pełni naukową. Zarówno on, jak i wszyscy pracownicy z Adamem Stebelskim, Jadwigą Karwasińską, Adamem Wolffem, ale również woźnym i magazynierem panem Wojciechem Zarębą otrzymali piórem Gieysztora pisane portrety, zaczynające się od opisu zewnętrznej postury, np. pana Adama Wolffa, który siedzial „przykuty swym potężnym wówczas ciężarem do Metryki Mazowieckiej i ksiąg sądowych Mazowsza", a kończące zobrazowaniem wiedzy i charakteru. Poznajemy też dzięki prezentowanemu tekstowi dokładne rozmieszczenie poszczególnych zespołów archiwalnych. Znajdujemy tam i taki opis:

Przejście z tego najważniejszego segmentu prowadziło przez kilka salek z aktami, przeważnie staropolskimi, do prawdziwego sacrosanctum, oznaczonego numerem sali IV, widocznym jeszcze dziś jako sygnatura na dokumentach pergaminowych. Jakoż tam, w sklepionej, zamczystej i dobrze zakratowanej izbie mieścił się zbiór dokumentów pergaminowych?

Nie ulega wątpliwości, że tak świadomy wszystkich swych działań człowiek, jakim był A. Gieysztor, stworzył po prawie 50 latach ten bardzo szczegółowy opis

7 A. Gieysztor, $W$ Archiwum Głównym prawie przed pótwieczem, Miscellanea Historico-Archivistica 2 (1987), s. 191.

8 Tamże, s. 190.

9 Tamże, s. 186. 
Archiwum Głównego jako świadectwo źródłowe rozplanowania archiwum sprzed drugiej wojny światowej i pracy ludzi wtedy w nim zatrudnionych. Podobny charakter relacji źródłowej naocznego świadka ma relacja Gieysztora z jego udziału w kampanii wrześniowej, powstała po latach na życzenie dowódcy dywizji, w której służył, i zacytowana przez Roberta Jarockiego w jego książce Widzieć jasno, bez za$c h w y t u^{10}$, a zwłaszcza relacja z powstania warszawskiego, opracowana wraz ze Stanisławem Płoskim w obozie jenieckim w końcu 1944 r. ${ }^{11}$ Ponadto A. Gieysztor miał niewątpliwie świadomość, że obszerna korespondencja, którą całe życie prowadził, a która stała się podstawą źródłową tekstu biograficznego napisanego przez Piotra Węcowskiego ${ }^{12}$, stanie się z czasem źródłem historycznym do biografii jego i jego korespondentów.

Jak widać, A. Gieysztor w sposób wyraźny i celowy zdobywał w czasach studiów kwalifikacje historyka zajmującego się historią Polski i to historią Polski średniowiecznej. Przypomnijmy, że chociaż wybrał studia historyczne zafascynowany lekturą monografii Władysława Semkowicza Ród Awdańców w wiekach średnich ${ }^{13}$, to jednak zdecydował się uczęszczać na seminarium magisterskie M. Handelsmana, który w tych latach otworzył ekskluzywne pięcioosobowe seminarium karolińskie. Wydaje się, że do wyboru tego seminarium przyczyniła się charyzmatyczna osobowość prof. Handelsmana i dyskretne skierowanie go w tę stronę przez ówczesnego docenta T. Manteuffla, który przyjrzał mu się dobrze na swoim proseminarium z historii średniowiecznej. Prof. Gieysztor zawsze zresztą głosił, że dobrze uprawiać historię Polski można jedynie na szerokim tle dziejów powszechnych. Pamiętajmy, że uczęszczał w czasie studiów również na drugie seminarium - Stanisława Kętrzyńskiego, skierowane na historię Polski w świetle materiału dyplomatycznego. Tak czy inaczej, dwie pierwsze poważniejsze prace A. Gieysztora - magisterska i doktorska - są pracami powszechnodziejowymi. Przedmiotem obu jest analiza źródeł. Podstawę pierwszej stanowi korespondencja między Karolem Wielkim a jego doradcą - mnichem anglosaskim Alkuinem ${ }^{14}$. Druga z tych prac - rozprawa doktorska

10 R. Jarocki, Zrozumieć innych (o Aleksandrze Gieysztorze), [w:] tenże, Widzieć jasno bez zachwytu, Warszawa 1982, s. 15-22.

11 A. Gieysztor, S. Płoski, Powstanie Warszawskie, Warszawa 1981; Powstanie Warszawskie. Rękopis Aleksandra Gieysztora. Gross Born listopad/grudzień 1944 r., Pultusk 2016.

12 Zob. w bieżącym tomie P. Węcowski, Aleksander Gieysztor w oczach wtasnych.

13 W. Semkowicz, Ród Awdańców w wiekach średnich, Poznań 1920.

14 A. Gieysztor, Wtadza Karola Wielkiego w opinii współczesnej, Warszawa 1938. 
o rzekomej encyklice papieża Sergiusza IV $^{15}$, której promotorem był podczas wojny, w 1942 r., S. Kętrzyński - jest pracą par excellence źródłoznawczą, najbardziej źródłoznawczą ze wszystkich, jakie Gieysztor kiedykolwiek napisał, i dlatego chciałabym tutaj w artykule o źródłach, źródłoznawstwie i metodach badawczych tego historyka bliżej się nią zająć.

Należałoby wspomnieć, że wkrótce po studiach i odbyciu służby wojskowej A. Gieysztor pojechał, wysłany przez obu swych opiekunów naukowych: M. Handelsmana i S. Kętrzyńskiego, na dodatkowe studia w ramach stypendium Funduszu Kultury Narodowej we francuskiej szkole archiwistów École nationale des chartes i École pratique des hautes études, gdzie trafił na seminarium Louisa Halphena, który zasugerował mu zajęcie się właśnie ową encykliką papieską. Z korespondencji A. Gieysztora wiadomo, że jego francuski mistrz miał na temat charakteru tego źródła wyraźnie sformułowaną hipotezę ${ }^{16}$, którą Gieysztor podbudował szczegółową analizą.

Podstawą dysertacji stała się kopia encykliki Sergiusza IV, na którego krótki i mało znaczący pontyfikat w latach 1009-1012 przypada zburzenie przez kalifa al-Hakima bazyliki Grobu Pańskiego w Jerozolimie. Wśród wcześniejszych badaczy zdania były podzielone na temat tego, czy bulla ta jest autentyczna, czy też fałszywa. Za jej autentycznością opowiedział się Carl Erdmann w pracy Die Entstehung des Kreuzzugsgedankens ${ }^{17}$, świeżo wówczas wydanej, bo w 1932 r. Dzięki temu badacz ten przesunął narodziny idei krucjatowej na początek XI w. Owa encyklika zachowała się w postaci dokumentu pergaminowego znacznych rozmiarów w Bibliothèque Nationale w Paryżu w kolekcji siedemnastowiecznego zbieracza o nazwisku Baluze, który ją odnalazł w zbiorze archiwaliów benedyktyńskiego klasztoru w Moissac, leżącego na południu Francji.

Gieysztor zaczyna, wzorem swego mistrza - Handelsmana - z jego Historyki, od krytyki erudycyjnej. Zwraca uwagę na wygląd zewnętrzny bulli, która nie ma pieczęci, ale rotę, która nie powinna się na tym dokumencie znaleźć, ponieważ wprowadziła ją na uroczystych dokumentach papieskich dopiero kancelaria Leona IX

15 Tenże, Ze studiów nad genezą wypraw krzyżowych. Encyklika Sergiusza IV (1009-1012), Warszawa 1948.

16 Zob. Listy Aleksandra Gieysztora (wybór), wyd. P. Węcowski, [w:] Aleksander Gieysztor. Człowiek i dzieło, red. M. Koczerska, P. Węcowski, Warszawa 2016, nr 2 (149), s. 502-503 (list Aleksandra Gieysztora do Tadeusza Manteuffla z 27 I 1939).

17 C. Erdmann, Die Entstehung des Kreuzzugsgedanken, Stuttgart 1932. 
40 lat późnej - w połowie XI w. (1049-1054) ${ }^{18}$. W analizowanym tekście znajduje przekręcenia wyrazów, wskazujące na to, że pisarz miał przed sobą brulion, który bezmyślnie i mechanicznie przepisywał. Zwraca uwagę na pismo, uznając je za jedenastowieczne, które jednak nie pozwala nam ściśle datować tego źródła, oraz cechy leksykalne, wskazujące raczej na obszar południowo-francuski niż na najlepszą w tym czasie kancelarię papieską. Przechodzi do zestawienia formul dokumentowych i zawartości treściowej bulli, porównując ten dokument z innymi, nielicznymi zresztą, bullami Sergiusza IV, i dochodzi do wniosku, że nie ma on cech produktu dyplomatycznego kancelarii papieskiej. Skończywszy tę egzegezę źródłoznawczą, przechodzi do ukazania okoliczności powstania bulli, kierując się ku kluniackiemu klasztorowi w Moissac, w którego zbiorach została znaleziona w XVII w. Zwraca uwagę na to, że papież Urban II, który ogłosił pierwszą krucjatę na synodzie w Clermont w 1095 r., sam będący - zanim został papieżem - mnichem kluniackim, podczas swej peregrynacji prokrucjatowej w latach 1095-1096 odwiedził i obdarował ten klasztor. W rozprawie tej Gieysztor dokonuje klasycznej analizy źródłoznawczej dokumentu. Jednak udowodnienie, że ta bulla stanowi falsyfikat, nie jest celem samym w sobie. Autor traktuje omawiany falsyfikat z końca XI w. jako ważne źródło do poznania idei krucjatowej i roli, jaką odegrały w jej głoszeniu klasztory benedyktyńskie kongregacji kluniackiej. Czyli ostatecznie falsyfikat ten służy mu jako źródło do poznania środków przekazu ideologii papiestwa czasów nie Sergiusza IV, ale jego następcy na Stolicy Piotrowej prawie 90 lat później - Urbana II.

O zainteresowaniach źródłoznawczych A. Gieysztora świadczy cały dział jego twórczości naukowej, który dotyczy nauk pomocniczych. Plonem tych zainteresowań, jak również potrzebą chwili był podręcznik Zarys nauk pomocniczych historii ${ }^{19}$, którego pierwszą wersję stanowił skrypt na potrzeby dydaktyczne dla Tajnej Wolnej Wszechnicy Polskiej, gdzie Gieysztor wykładał w latach wojny. Jest zrozumiałe, że właśnie w tym zakresie - nauk pomocniczych - czuł się najbardziej kompetentny, ale budzi niemałe zaskoczenie, że nie wątpił w użyteczność tego przedmiotu dla słuchaczy, rekrutujących się spośród żołnierzy Batalionów Chłopskich ${ }^{20}$. Można sądzić, nie mając jednak możliwości bazowania na zachowanej opinii samego Profesora, że chciał swoim słuchaczom przedstawić podstawy warsztatu naukowego historyka

\footnotetext{
18 A. Gieysztor, Ze studiów, s. 25.

19 Powszechnie do dzisiaj wykorzystywane jest III wydanie tego skryptu: A. Gieysztor, Zarys nauk pomocniczych historii, 2 t., wyd. III, rozszerzone przy współudziale S. Herbsta, Warszawa 1948.
}

$20 \quad$ Nauka jako stużba, s. 118. 
specjalisty w zakresie średniowiecza i wczesnej nowożytności, który nie może się obyć w krytyce źródła bez znajomości paleografii, chronologii, genealogii, heraldyki $\mathrm{i}$ innych nauk pomocniczych historii.

Tą nauką pomocniczą, którą szczególnie się interesował, była paleografia. Wydaje się, że taki wybór miał wielorakie przyczyny. Jak wiadomo, każda praca historyka $\mathrm{z}$ nowym źródłem historycznym odnalezionym $\mathrm{w}$ archiwum lub gdziekolwiek indziej zaczyna się od jego odczytania. Praktykując w Archiwum Głównym, a następnie przechodząc wyczerpujący program nauczania w École des chartes, Gieysztor nabrał biegłości w czytaniu tekstów z odległych epok i poznał przyjemność, jaką daje paleografowi odczytanie tekstu, przedstawiającego znaczne trudności - wyblakłego przez czas i wilgoć lub po prostu pisanego przez pisarza, który nie przejmował się, że ktoś po kilkuset latach będzie miał trudności z odczytaniem jego notatek. Przykładem czerpania przyjemności z rozwiązywania zagadek paleograficznych są dwa artykuły - pierwszy z 1959 r. zamieszczony w trzytomowej publikacji studiów o Drzwiach Gnieźnieńskich pod redakcją Michała Walickiego ${ }^{21}$ i drugi ze schyłku jego życia, wydany w 1997 r. w studiach ofiarowanych jego długoletniemu przyjacielowi, ojcu Pawłowi Sczanieckiemu, w zbiorze pt. Benedyktyńska praca ${ }^{22}$. W obu wypadkach Gieysztor włączał się do dyskusji innych paleograficznych sław - w pierwszym wypadku Zofii Budkowej i Adama Wolffa oraz Lecha Kalinowskiego; w drugim - Brygidy Kürbis. Rozwiązywanie zagadek paleograficznych przez A. Gieysztora pozwala poznać jeszcze jedną z jego pasji i pobudek poznania - odczytanie źródła, równoznaczne z jego zrozumieniem, jako rodzaj rozrywki umysłowej, dla samej przyjemności poznania.

Najważniejszym jednak jego dziełem w zakresie tej nauki pomocniczej historii jest podręcznik akademicki Zarys dziejów pisma łacińskiego, opublikowany drukiem w 1973 r. $^{23}$, jako ostatni z serii podręczników Nauki pomocnicze historii, wydanych przez Instytut Historii PAN pod redakcją T. Manteuffla. Wcześniejsze tomy tej serii dotyczyły chronologii, genealogii, numizmatyki, sfragistyki i dyplomatyki ${ }^{24}$. Miała

21 A. Gieysztor, O napisach na Drzwiach Gnieźnieńskich, [w:] Drzwi Gnieźnieńskie, red. M. Walicki, t. 2, Warszawa 1959, s. 415-420.

22 Tenże, List Arona biskupa krakowskiego: następna próba odgadnięcia tekstu, [w:] Benedyktyńska praca. Studia historyczne ofiarowane o. Pawtowi Sczanieckiemu w 80-rocznice urodzin, red. J.A. Spież, Z. Wielgosz, Tyniec 1997, s. 45-48.

23 Tenże, Zarys dziejów pisma łacińskiego, Warszawa 1973, reprint Warszawa 2009.

24 Chronologia polska, red. B. Włodarski, Warszawa 1957, reprint Warszawa 2007; W. Dworzaczek, Genealogia, 2 t., Warszawa 1959; R. Kiersnowski, Pieniadz kruszcowy w Polsce wcze- 
ona w zamyśle jej inicjatora T. Manteuffla wypełnić lukę w rozwoju nauk pomocniczych historii, spowodowaną nieformalnym zakazem ich uprawiania w Polsce w pierwszych latach powojennych. Idea napisania przez A. Gieysztora nowego podręcznika paleografii w tej serii powstała już w $1954 \mathrm{r}^{25}$, ale dopiero możliwość dostępu do nowej literatury przedmiotu i pełnej koncentracji na pisaniu podczas trwania stypendium w Oksfordzie w latach 1968-1969 doprowadziła do powstania tej syntezy. W przeciwieństwie do innych europejskich podręczników paleografii książka A. Gieysztora nie ogranicza się tylko do pisma średniowiecznego, lub głównie do materiału polskiego jak podręcznik Władysława Semkowicza ${ }^{26}$, ale przedstawia pismo łacińskie w rozwoju historycznym od starożytnych początków do pisma odręcznego w XIX i XX w. Autor traktuje pismo jako integralną, a może najważniejszą część kultury i komunikacji społecznej. W skoncentrowanej treści podręcznika czytelnik znajdzie zarysowane linie przemian pisma, zróżnicowanie i definicje jego gatunków w zależności od przeznaczenia prywatnego lub instytucjonalnego, ale również wiadomości praktyczne np. z zakresu brachygrafii, czyli teorii i praktyki tworzenia skrótów paleograficznych.

Nie wszyscy wiedzą, że A. Gieysztor był również niepospolitym znawcą heraldyki. Świadczą o tym jego przedwojenne - z czasów stażu w Archiwum Głównym - prace publikowane w „Miesięczniku Heraldycznym”27. Ci, którzy uprawiali heraldykę, znajdowali w nim kompetentnego doradcę w różnych zawiłościach historycznej i praktycznej heraldyki, również heraldyki państwowej po zmianie ustroju w 1989 r. Z jego seminarium wyszły prace Henryka Andrulewicza o genezie godła państwowego w czasach piastowskich ${ }^{28}$ i Stefana K. Kuczyńskiego - o sfragistyce książąt mazowieckich ${ }^{29}$. S. Kuczyński był również doskonałym znawcą heraldyki

snośredniowiecznej, Warszawa 1960; M. Gumowski, M. Haisig, S. Mikucki, Sfragistyka, Warszawa 1960; K. Maleczyński, M. Bielińska, A. Gąsiorowski, Dyplomatyka wieków średnich, Warszawa 1971.

25 Jako potencjalnego autora podręcznika paleografii w nowej serii wskazywało Gieysztora jego studium nad karolińską reformą pisma - A. Gieysztor, Problem karolińskiej reformy pisma, Archeologia 5 (1952-1953), s. 155-177.

26 W. Semkowicz, Paleografia łacińska, Kraków 1951, II wyd. Kraków 2002.

27 Zob. Bibliografia prac Aleksandra Gieysztora za lata 1935-1975, zestawily M. Koczerska, E. Suchodolska, J. Zwolińska, [w:] Cultus et cognitio. Studia z dziejów średniowiecznej kultury, red. S.K. Kuczyński, Warszawa 1976, s. 9-10.

28 H. Andrulewicz, Geneza Orła Białego jako herbu Królestwa Polskiego w roku 1295, Studia Źródłoznawcze 13 (1968), s. 1-26.

29 S.K. Kuczyński, Pieczęcie książąt mazowieckich, Wrocław 1978. 
i współautorem projektu dekoracji heraldycznej Izby poselskiej w Zamku Królewskim w Warszawie.

Ze studiów paleograficznych A. Gieysztora poznajemy jeszcze jedną ważną pobudkę najpierw studiowania, a następnie uprawiania nauki - walor estetyczny. Taki powód widzimy - poza wszystkimi innymi - w studiowaniu równoległym w czasach studiów uniwersyteckich historii sztuki pod kierunkiem Zygmunta Batowskiego. O tym świadczy kolekcjonowanie pięknej książki i grafiki w czasach wojny, kiedy uczestniczył w zakonspirowanych spotkaniach kolekcjonerów. „W tamtych latach - wspominał w wywiadzie - byłem naprawdę z przekonania bibliofilem. Kiedy straciłem w czasie Powstania cały swój zbiór książek i grafik, a był już naprawdę niezły, to przez wiele lat w ogóle ich nie zbierałem. [...] a kolekcjonerstwo zaginęło wśród innych moich pasji życiowych" ${ }^{30}$.

Największym dziełem źródłoznawczym A. Gieysztora, stworzonym wspólnie z Gerardem Labudą, którzy niebawem zaprosili do współpracy B. Kürbis, jest rocznik „Studia Źródłoznawcze”. Samą ideę stworzenia tego pisma należy przypisać, jak wynika z korespondencji między obu uczonymi - prof. Labudzie. Odpowiadało to niewątpliwie dążeniom środowiska mediewistycznego, odczuwającego potrzebę wyspecjalizowanego czasopisma, gotowego na druk miscellaneów (niekiedy pokaźnych rozmiarów) z dziedziny nauk pomocniczych, wzorcowych i wzorowych edycji źródeł niewielkich rozmiarów oraz rozpraw teoretycznych. Pomysł ten realizował z właściwą sobie energią i talentem, jak również nieustępliwością A. Gieysztor, pokonując bariery ze strony decydentów ministerialnych, a nawet środowiska historycznego ${ }^{31}$, jak to pokazał w swoim tekście na podstawie zachowanej korespondencji Piotr Węcowski ${ }^{32}$. W rezultacie powstało czasopismo o wyraźnie mediewistycznym profilu, ale dopuszczające również teksty dotyczące źródeł wczesnonowożytnych i późniejszych. Publikacje z zakresu spraw źródłoznawstwa późnonowożytnego i współczesnego usiłowano sobie zapewnić, włączając w skład redakcji specjalistów dziejów późniejszych, czyli Ireneusza Ihnatowicza od 1969 r. i Emanuela Rostworowskiego w połowie lat siedemdziesiątych. Doskonałą wizytówką nowego czasopisma był jego pierwszy tom opublikowany w 1957 r., w którym znalazł się metodologiczny artykuł G. Labudy o nowej systematyce źródeł historycznych i B. Kürbisówny o metodyce

\footnotetext{
$30 \quad$ Nauka jako stużba, s. 121.

31 W sprawie trudnego rodzenia się Studiów Źródłoznawczych zob. Listy Aleksandra Gieysztora, nr 8(92), 9(93), 11(95), 12(96), 13(97) - listy Aleksandra Gieysztora do Gerarda Labudy oraz tamże, nr 1(65) - list do Brygidy Kürbisówny.

32 Zob. w bieżącym tomie P. Węcowski, Aleksander Gieysztor w oczach własnych.
} 
wydawania źródeł historiograficznych, jak również instrukcje wydawnicze: pióra A. Wolffa, która miała zastąpić instrukcję PAU z 1925 r. oraz Zofii Budkowej, Marii Friedbergowej i B. Kürbisówny - dla wydawnictwa roczników polskich. W dziale Dyskusje znalazł się ponadto tekst G. Labudy i B. Kürbisówny o nowej serii Monumenta Poloniae Historica. Jednym z największych osiągnięć tego nowego rocznika były działy recenzji i zapisek krytycznych, z bogato reprezentowaną literaturą obcą, które dawały uczonym „za żelazną kurtyną” możliwość informacji bibliograficznej. Często zaczynaliśmy sporządzanie bibliografii od wertowania tych działów kolejnych roczników „Studiów Źródłoznawczych”.

Pora wrócić do wcześniejszych zainteresowań i aktywności organizacyjnej A. Gieysztora, które poszerzały zakres wykorzystywanych przezeń źródeł i jego wiedzy źródłoznawczej. Poruszano wielokrotnie problem jego działań w latach 1949-1953 w Kierownictwie Badań nad Początkami Państwa Polskiego. Koncepcja szeroko zakrojonych badań przewidywała prace wykopaliskowe na ponad dwudziestu obiektach, które obejmowały główne ośrodki grodowe i kościelne państwa piastowskiego, takie jak Gniezno, Poznań, Ostrów Lednicki, Giecz, Biskupin (ale wczesnośredniowieczny, nie łużycki), Kruszwica, Kalisz, Tum pod Łęczycą, Wawel w Krakowie, Wiślica, Cieszyn, Opole, Wrocław, Niemcza, Gdańsk, Szczecin, Wolin, a także góra Ślęża-Sobótka i zespół Grodów Czerwieńskich - najtrudniejsze w realizacji ze względu na konieczność uzyskania zgody na prowadzenie badań ze strony wschodniego sąsiada ${ }^{33}$.

Wahania przy podejmowaniu decyzji o kierowaniu tym przedsięwzięciem badawczym były zrozumiałe, jednak za przyjęciem tej propozycji przemawiało wiele względów natury ogólnej i osobistej. A. Gieysztor otrzymywał bardzo szerokie pole badań i niezależne stanowisko administracyjne, pozwalające realizować własną koncepcję badawczą; mógł w ten sposób doprowadzić do przysporzenia polskiej nauce historycznej nowych źródeł, które miały pozwolić na uzupełnienie obrazu Polski wczesnopiastowskiej znanego na bazie wątłej podstawy źródeł pisanych; otwierała się przed nim możliwość poznania archeologicznych metod badawczych i interesującej wartości źródeł materialnych, choć wymagało to znacznego i szybkiego przygotowania w nowej dla niego nauce. Gieysztor zdawał sobie już wtedy niewątpliwie sprawę, że otworzy się parasol ochronny przed możliwymi represjami politycznymi nad nim i wszystkimi zatrudnionymi w Kierownictwie Badań, jak Ryszard Kiersnowski, Maria Dembińska, Teresa Dunin-Wąsowicz i wiele innych osób. Poza tym gnała

33 Zob. R. Kiersnowski, Wspominając Aleksandra Gieysztora: w „Millenium”, Przegl. Hist. 91 (2000), z. 1, s. 61-67. 
go do tego ciekawość świata i chęć rozpoczęcia nowego wątku swych badań, jak również nowego rozdziału w życiu. Owa ciekawość świata, dotychczas nieznanego, była chyba dla prof. Gieysztora jednym z ważnych motorów działania. Rozmach i rozległe perspektywy tego projektu badawczego są widoczne również w stworzeniu komórki edytorskiej, która miała wypełnić dawny, stawiany już przed wojną postulat badawczy, a mianowicie nowej edycji źródeł wydanych niegdyś w serii Monumenta Poloniae Historica. Po zakończeniu w 1953 r. tego programu badawczego pracownia ta przeszła najpierw do nowo powstałego Instytutu Historii Kultury Materialnej, a następnie - Instytutu Historii PAN.

Działalność w Kierownictwie Badań nad Początkami Państwa Polskiego zaowocowała dla A. Gieysztora wielorako i dalekosiężnie. Wydaje się, że można za Janem Tyszkiewiczem ${ }^{34}$ wskazać jako pracę odzwierciedlającą najlepiej wzbogacenie warsztatu, jakie mu przyniosło kierowanie tą placówką, artykuł opublikowany po latach, bo 1967 r. w Studiach sandomierskich o krajobrazie międzyrzecza Pilicy i Wisły we wczesnym średniowieczu ${ }^{35}$. Autor zajmuje się w nim uwarunkowaniami naturalnymi i śladami osadniczymi włączenia tego terytorium do państwa Piastów u zarania jego ekspansji terytorialnej. W tekście nie pada ani jedno zdanie o podstawie źródłowej prezentowanych rozważań, ale z przedstawionego kwestionariusza badawczego i rezultatów widzimy, że autor czerpał z ustaleń geologów i geografów historycznych co do jakości gleb na omawianym terytorium, będących podstawą rozwoju osadnictwa; z wyników wykopalisk archeologicznych dla podkreślenia znaczenia takich grodów, jak np. Wiślica; z dziewiętnastowiecznej mapy kwatermistrzostwa, aby ustalić topografię terenu, a głównie zasięg lasów w epoce preindustrialnej; z nazewnictwa miejscowego, zwłaszcza w zakresie nazw służebnych, które świadczą o strukturach administracyjnych i gospodarczych pierwszej monarchii piastowskiej. Doskonałe wyczucie przez Gieysztora potencjału źródłowego tkwiącego w nazewnictwie miejscowym ukazuje ten fragment artykułu, w którym Autor zajmuje się tzw. etnicznymi nazwami miejscowości. Należy do nich nazwa Mazowszany pod Radomiem oraz nazwy takie jak Klwaty, Klwatka (dawniej Chrwaty), również koło Radomia ${ }^{36}$. Pierwsza z nich dowodzi przymusowego przeniesienia Mazowszan na ten teren i wskazuje na to, że traktowano ich pod Radomiem jako ludność obcą w stosunku

\footnotetext{
34 J. Tyszkiewicz, Z perspektywy lat, [w:] Aleksander Gieysztor. Człowiek i dzieło, s. 325.

35 A. Gieysztor, Krajobraz międzyrzecza Pilicy i Wisty we wczesnym średniowieczu, [w: ] Studia sandomierskie. Materiały do dziejów miasta Sandomierza i regionu sandomierskiego, red. T. Wąsowicz, J. Pazdur, [Warszawa] 1967, s. 11-37.
}

36 Tenże, Krajobraz międzyrzecza, s. 23. 
do miejscowych, a więc nie pozwala na uznanie jedności etnicznej sąsiednich krain wbrew mniemaniu niektórych badaczy. Te drugie wskazują na kolebkę Chorwatów późniejszego plemienia południowosłowiańskiego.

Jeszcze bardziej zainteresowania A. Gieysztora geografią historyczną dowodzi cykl artykułów dotyczących dziejów dzielnic Warszawy, zwłaszcza jej dzielnic peryferyjnych. Cykl ten rozpoczął się opublikowaniem w 1970 r. najstarszych dziejów Żoliborza ${ }^{37}$ i Pragi ${ }^{38}$, a objął ponadto Mokotów ${ }^{39}$, Ochotę ${ }^{40}$, Wolę ${ }^{41}$ i Śródmieście ${ }^{42}$, które pomieściło dzieje Starego i Nowego Miasta, Zamku Królewskiego, Jazdowa i obecnego centrum stolicy. W ten sposób już wtedy, w latach siedemdziesiątych, powstała pełna historia Warszawy, mając zresztą poprzednika w pracy zbiorowej z 1947 r. pt. Kształty Warszawy ${ }^{43}$. Jak zawsze, co A. Gieysztor wyraźnie stwierdza44 ${ }^{44}$, $\mathrm{w}$ dziejach miasta najważniejszą rolę odgrywał człowiek i to ludzie byli sprawcami powstania i funkcjonowania miasta. Ci właśnie ludzie wybierali te, a nie inne warunki fizjograficzne i przekształcali je dla swych celów. Do przedstawienia dzielnic peryferyjnych, jaką był np. aż do połowy XVIII w. Żoliborz, na którego miejscu istniała od średniowiecza wieś o nazwie Polikowo, potrzebna była dogłębna znajomość ukształtowania terenu z jego siecią hydrograficzną warunkującą rozwój przemysłu napędzanego siłą wody, jakością gleb, która umożliwiała rolnicze wykorzystanie ziemi. Przy okazji jesteśmy świadkami doskonałej znajomości topografii terenu i umiejscowienia owych pól, młynów, blechów i foluszy w miejscu konkretnych dzisiejszych ulic miasta, których etymologia nazw jest często świadectwem roli w przeszłości.

37 Tenże, Pradzieje żoliborskie: od wczesnego średniowiecza do połowy XVIII wieku, [w:] Żoliborz wczoraj, dziś, jutro, red. J. Zahorska, Warszawa 1970, s. 9-24.

38 Tenże, Praga najstarsza (między X i XIV w.), [w: ] Dzieje Pragi, red. J. Kazimierski, Warszawa 1970, s. 7-24.

39 Tenże, Na południe od Warszawy przed połowa XVIII w., [w:] Dzieje Mokotowa, red. J. Kazimierski i in., Warszawa 1972, s. 17-35.

40 Tenże, Wiejscy poprzednicy Ochoty do połowy XVII w., [w:] Dzieje Ochoty, red. J. Kazimierski i in., Warszawa 1973, s. 15-27.

41 Tenże, Wielka Wola a Warszawa średniowieczna, [w:] Dzieje Woli, red. J. Kazimierski i in., Warszawa 1974, s. 19-28.

42 Tenże, Śródmieścia Warszawy dzieje starsze, [w: ] Dzieje Śródmieścia, red. J. Kazimierski i in., Warszawa 1975, s. 29-46.

43 A. Gieysztor, S. Herbst, E. Szwankowski, Ksztatty Warszawy, Biuletyn Historii Sztuki i Kultury 9 (1947), s. 148-210.

44 A. Gieysztor, Śródmieścia Warszawy, s. 30. 
Praca w zespole Millenium odnowiła i zwielokrotniła zainteresowanie Aleksandra Gieysztora zabytkami sztuki zapoczątkowane w latach studiów i stworzyła możliwość wykorzystania różnych obiektów wykopaliskowych, a zwłaszcza obiektów kultowych - figurek z czasów pogańskich. Przypuszczam, że może nie otrzymalibyśmy w 1982 r. jego Mitologii Stowian, albo powstałoby dzieło oparte na mniejszej liczbie i mniej różnorodnych źródłach historycznych, gdyby nie udział w tych millenijnych badaniach.

Obiekty materialne: przedmioty symboliczne i ich graficzne wyobrażenia stały się podstawą źródłową kolejnego wątku badawczego w twórczości naukowej A. Gieysztora. Myślę tu o artykule z 1969 r. opublikowanym w księdze pamiątkowej Stanisława Lorentza ${ }^{45}$, z którym Gieysztora łączyły więzi typu Mistrz i uczeń, ponieważ Lorenz był jego nauczycielem historii jeszcze w liceum, a potem zaraz po wojnie zatrudnił go w Naczelnej Dyrekcji Muzeów i Ochrony Zabytków, która była również organem zwierzchnim w stosunku do Kierownictwa Badań nad Początkami Państwa Polskiego.

W artykule, o którym teraz mowa, przedstawiającym przejście królów polskich od używania korony otwartej do posługiwania się koroną zamkniętą, na tle analogicznego zjawiska w innych państwach późnośredniowiecznej i wczesnonowożytnej Europy, Gieysztor nawiązał do fundamentalnych badań Percy'ego Ernsta Schramma o insygniach władzy i symbolice państwowej ${ }^{46}$. Artykuł ten jest przykładem stosowania przez A. Gieysztora metody porównawczej, ponieważ prawie połowę tekstu artykułu zajmuje pokazanie okoliczności i czasu wprowadzenia korony zamkniętej w Anglii i Francji - zawsze w kontekście stosunku tych państw do Cesarstwa i dla wykazania równorzędności królów angielskich i francuskich wobec cesarza. Badając te zagadnienia na gruncie polskim, uczony wykorzystał źródła różnorodnego charakteru, głównie ikonograficzne i sfragistyczne, ponieważ to na pieczęci koronacyjnej Jana Olbrachta pojawiła się po raz pierwszy korona zamknięta nad tarczą herbową. Królowie polscy zaczęli używać korony zamkniętej głównie w stosunkach z innymi władcami, i tak Zygmunt Stary użył tej nowej korony, przyjmując hołd lenny Albrechta Hohenzollerna.

45 Tenże, „Non habemus caesarem nisi regem”. Korona zamknięta królów polskich w końcu XV wieku i w wieku XVI, [w:] Muzeum i twórca. Studia z historii sztuki i kultury ku czci prof. dr S. Lorentza, Warszawa 1969, s. 277-292. Nowe wydanie tego artykułu: A. Gieysztor, Wtadza, symbole i rytuaty, red. P. Mrozowski, P. Tyszka, P. Węcowski, Warszawa 2016, s. 73-98. 46 P.E. Schramm, Herrschaftszeichen und Staatssymbolik. Beiträge zur Geschichte vom dritten zum sechszehnten Jahrhundert, t. 1-3, Stuttgart 1955-1956. 
Do tego samego nurtu badawczego w twórczości A. Gieysztora należy cykl artykułów o polskiej koronacji królewskiej ${ }^{47}$ od późnego średniowiecza poczynając, ponieważ pisemne polskie ordo coronandi zachowało się z połowy $\mathrm{XV} \mathrm{w} .^{48}$ oraz w zachowanych ceremoniałach - nowożytnych instrukcjach koronacyjnych kolejnych królów Polski, aż do koronacji Stanisława Augusta Poniatowskiego w 1764 r. W tym cyklu artykułów Autor zwraca szczególną uwagę na utrwalone przez owe ordines nie tylko słowa koronowanego, który w Polsce dopiero po koronacji stawał się królem, i koronatora - arcybiskupa gnieźnieńskiego, ale równie ważne w tej ceremonii gesty $^{49}$ oraz uczestnictwo w całym cyklu uroczystości koronacyjnych wąskiej grupy stanowiącej elitę społeczną oraz całego tłumu towarzyszącego elektowi w procesji z Wawelu na Skałkę i z powrotem, a także na Rynek krakowski - już koronowanemu władcy.

Nie ulega wątpliwości, że Stanisław Lorentz, Jan Zachwatowicz i A. Gieysztor traktowali odbudowę Zamku Królewskiego w Warszawie jako przywrócenie Warszawie i całej Polsce znaku pełnej suwerenności dawnej Rzeczypospolitej. Równocześnie było to przywrócenie miastu najlepiej zachowanego i największego zabytku architektury gotyckiej, jaką stanowią piwnice zamkowe, co wielokrotnie podkreślał przy oprowadzaniu po nich prof. Gieysztor. Głównie dzięki jego koncepcji urządzenia Zamku powstało tam muzeum wnętrz, mieszczące pozostałości przedwojennego Zamku i stale uzupełniane przez nowe nabytki, a nie rezydencja władzy PRL-u. Refleksje na temat stosunku historyka do zabytku, w tym zabytku sztuki, musiały towarzyszyć A. Gieysztorowi od początku jego pracy jako historyka, a nawet w czasach studenckich, kiedy zdecydował się na równoległe studiowanie historii sztuki. Problematyka ta wróciła ze zdwojoną siłą po drugiej wojnie światowej, kiedy w Polsce i w całej Europie tak wiele zabytków uległo zagładzie. Powstały w 1978 r. tekst Zabytek w oczach historyk $a^{50}$ jest jednym z nielicznych, w których Profesor

47 A. Gieysztor, Spektakl i liturgia - polska koronacja królewska, [w:] Kultura elitarna a kultura masowa w Polsce późnego średniowiecza, red. B. Geremek, Wrocław 1978, s. 9-23. Zarówno ten artykuł, jak i wszystkie pozostałe dotyczące tematyki koronacji królów polskich zostały opublikowane ponownie w: A. Gieysztor, Wtadza, symbole i rytuaty, s. 21-119.

48 Zob. Ordo coronandi regis Poloniae, wyd. S. Kutrzeba, Archiwum Komisji Historycznej AU, t. 11, Kraków 1919, s. 133-216.

49 Zob. szczególnie A. Gieysztor, Rola gestu w ceremonii koronacyjnej w Polsce średniowiecznej, [w:] tegoż, Wtadza, symbole i rytuały, s. 49-60. Tekst pierwotny był w języku francuskim. 50 Był to tekst referatu wygłoszonego przez A. Gieysztora w 1978 r. w Toruniu, na sesji poświęconej znakomitemu konserwatorowi zabytków Jerzemu Remerowi. Zob. tenże, Zabytek w oczach historyka, [w:] Konserwator i zabytek. In memoriam Jerzego Remera, Warszawa 
dzieli się swoją refleksją o źródle historycznym, ale o źródle szczególnego rodzaju, jakim jest zabytek, a zwłaszcza dzieło sztuki, oraz o roli konserwatora sztuki. Niejako przy okazji nawiązuje do definicji źródła historycznego, która należy do najszerszych z możliwych, sformułowanej przez brytyjskiego historyka Robina G. Collinwooda, że „Wszystko na świecie jest potencjalnym świadectwem dla każdego tematu” ${ }^{\text {. }}$. Zabytek pełni dla historyka rolę źródła bezpośredniego, ale do jego rozumienia, czyli interpretacji niezbędna mu jest wiedza czerpana ze źródeł pośrednich. Zabytki różnego rodzaju, będące zabytkami architektury, kultury wytwórczości materialnej oddziałują nie tylko na umysł historyka, będąc źródłem wiedzy, ale również emocji. Autor rozważa też problem stojący zarówno przed konserwatorami zabytków i historykami, jak i przed szerszymi kręgami społecznymi. Jest to pytanie o sens odbudowywania kompletnie zniszczonych zabytków. Gieysztor odpowiadał na to pytanie, podając dwa powody - pierwszy został już wspomniany na początku tego akapitu - odbudowuje się symbole własnej suwerenności dla jej zaakcentowania. W tym artykule znajdujemy jeszcze inne wytłumaczenie takich działań. To mianowicie, że wszystkie zabytki niszczeją z biegiem czasu, i w każdym z nich, z Wawelem i katedrą krakowską włącznie, znajdujemy elementy, które dodano w ciągu wieków - w mniej lub bardziej odległej przeszłości, mając na uwadze, że conservatio est aeterna creatio.

Wspomnieć jeszcze należałoby o późnym dziele A. Gieysztora, Mitologii Sto$w_{i a n^{52}}$, w którym wykorzystal, obok źródeł pisanych, zabytki kultowe pozyskane dzięki wykopaliskom archeologicznym, źródła lingwistyczne oraz przede wszystkim - folklorystyczne. Dzięki temu i oparciu się na koncepcji funkcjonalizmu Georges’a Dumézila, powstał w książce Gieysztora stosunkowo spójny świat bogów i duchów słowiańskich.

A. Gieysztor nie pozostawił po sobie żadnego tekstu o wyraźnie metodologicznym charakterze. Uwagi o metodologii historii znajdujemy natomiast w jego pracach omawiających twórczość innych historyków, a zatem w pracach z dziedziny historii historiografii oraz w recenzjach z prac o charakterze metodologicznym i metodycznym. Najwięcej takich refleksji znajdziemy we wstępach i posłowiach do prac czterech historyków, z którymi czuł się szczególnie związany, a mianowicie Tadeusza

1991, s. 11-16; II wyd. wg komputerowego tekstu referatu z 1978 r., [w: ] A. Gieysztor, O dziedzictwie kultury, red. D. Gawin i in., Warszawa 2000, s. 157-163.

51 A. Gieysztor, Zabytek, s. 12 za: R.G. Collingwood, The Idea of History, Oxford 1946, s. 714.

52 A. Gieysztor, Mitologia Słowian, Warszawa 1982; tenże, Mitologia Słowian, wyd. 3 zmienione i rozszerzone, wstęp K. Modzelewski, posłowie L.P. Słupecki, oprac. na podst. rękopisu A. Pieniądz, Warszawa 2006. 
Wojciechowskiego ${ }^{53}$, Stanisława Smolki ${ }^{54}$, Marcelego Handelsmana ${ }^{55}$ i Stanisława Kętrzyńskiego ${ }^{56}$. Dwóch ostatnich był uczniem, a dwóch pierwszych naukowym wnukiem. Wszyscy, którzy znali A. Gieysztora, wiedzą, że odczuwał on szczególną przyjemność z budowania genealogii naukowej - swojej i innych historyków. Sam pisał o tym w szkicu o S. Smolce ${ }^{57}$, a o tym jego upodobaniu pisał w swym wspomnieniu o Profesorze Mieczysław Rokosz ${ }^{58}$.

Do T. Wojciechowskiego miał szczególny sentyment. Za fenomen uznawał Szkice historyczne XI wieku - jego najpopularniejsze dzieło, które wywarło ogromny wpływ na polską historiografię. Było to późne dzieło tego historyka - liberalnego konserwatysty, jak go określa Gieysztor ${ }^{59}$, a równocześnie samotnika i introwertyka - bo wydane po raz pierwszy w 1904 r., gdy autor - profesor Uniwersytetu Lwowskiego - miał już 66 lat. Wywołało ono burzę krytyki ze względu na negatywne przedstawienie biskupa Stanisława, na którą autor z werwą odpowiedział w replice zatytułowanej: Plemię Kadtubka. Prawdopodobnie głównie ze względu na to dzieło Gieysztor określał Wojciechowskiego w zakresie metodyki jako przedstawiciela metody dedukcyjnej i intuicjonistę. $Z$ drugiej strony podkreślał jego trzymanie się źródeł, ale to raczej ze względu na wcześniejszą monografię katedry wawelskiej ${ }^{60}$. Ta była mu bliska dzięki uznaniu przez Wojciechowskiego znaczenia zabytku sztuki jako źródła historycznego. Szczególnie cenil jego wczesne dzieło, a mianowicie Chrobację $e^{61}$ a to

53 Tenże, Wstęp, [w:] T. Wojciechowski, Szkice historyczne XI wieku, przygotował do druku i wstępem poprzedził A. Gieysztor, Warszawa 1970, s. 5-23.

54 Tenże, Posłowie, [w:] S. Smolka, Mieszko Stary i jego wiek oraz Uwagi o pierwotnym ustroju społecznym Polski piastowskiej, do przedruku przygotował i posłowiem opatrzył A. Gieysztor, Warszawa 1959, s. 649-672, a przede wszystkim: tenże, Stanisław Smolka jako mediewista, [w: ] Spór o historyczną szkołę krakowska, red. C. Bobińska, J. Wyrozumski, Kraków 1972, s. 95-118. 55 Tenże, Posłowie, [w: ] M. Handelsman, Średniowiecze polskie i powszechne. Wybór pism, Warszawa 1966, s. 351-371.

56 Tenże, Posłowie, [w:] S. Kętrzyński, Polska X-XI w., Warszawa 1961, s. 693-712.

57 Tenże, Stanisław Smolka, s. 115: „Do mitów rozwijanych ze szczególnym upodobaniem należy też genealogia naukowa, wywodzenie się ze szkoły mistrza, a pośrednio z cechu, do którego należał sam mistrz, i dalej, co najmniej do bogów historiografii romantycznej i herosów historiografii krytycznej”.

58 M. Rokosz, O profesorze Gieysztorze - migawki wspomnień, [w:] Aleksander Gieysztor. Człowiek i dzieło, s. 286.

59 A. Gieysztor, Wstęp, [w:] T. Wojciechowski, Szkice, s. 16.

60 T. Wojciechowski, Kościót katedralny w Krakowie, Kraków 1900.

61 Tenże, Chrobacja. Rozbiór starożytności słowiańskich, t. 1, Kraków 1873. 
ze względu na twórcze wykorzystanie źródeł toponomastycznych. Tej to monografii środowisko naukowe Krakowa nie uznało w 1873 r. za godną habilitacji jej autora. Już ten krótki przegląd twórczości T. Wojciechowskiego przekonuje, jak bliski był A. Gieysztorowi dzięki zainteresowaniom i metodom badawczym.

Szkicując postać S. Smolki jako mediewisty, poświęcił najwięcej uwagi jego dziełu Mieszko Stary i jego wiek, traktując go właściwie jako autora unius libri, chociaż docenił również jego pracę doktorską o rocznikach polskich pisaną w Getyndze pod kierunkiem Georga Waitza oraz późniejszą monografię Jana Długosza, którą Smolka opracował wspólnie z Michałem Bobrzyńskim. Nie dość na tym, że potraktował Smolkę jako autora jednej książki, to jeszcze wskazał wyraźnie, że o jej znakomitości przesądza tylko pierwsza jej część dotycząca krajobrazu przyrodniczego oraz podstaw gospodarczo-społecznych epoki Mieszka Starego, podczas gdy portret samego księcia wypadł blado, a również w przedstawieniu historii politycznej wiele twierdzeń wymagało poprawienia. Gieysztorowi nie odpowiadał również styl S. Smolki, który pragnął swoją kwiecistością przyciągnąć szerszego czytelnika. Natomiast $\mathrm{z}$ niekłamanym podziwem zanotował, że Smolka napisał to potężne dzieło w wieku 25-26 lat w ciągu 11 tygodni. Podobnie chwalił uzupełnienie metody genetyczno-ewolucyjnej stosowaniem retrogresji przy wykorzystaniu źródeł trzynastowiecznych dla przedstawienia właśnie owych gospodarczo-społecznych podstaw Polski czasów Mieszka Starego. Za liczące się osiągnięcie krakowskiego mistrza uznał również wychowanie całego pocztu znakomitych doktorów.

Owe osiągnięcia dydaktyczne Gieysztor zawsze traktował niemal na równi z osiągnięciami naukowymi i podkreślał je również w portretach swych dwóch bezpośrednich mistrzów: M. Handelsmana i S. Kętrzyńskiego. W Postowiu do Średniowiecza polskiego i powszechnego Handelsmana uznał nawet, że „zapewnienie swoim pracom i zamierzeniom kontynuacji” stanowi „jeden z podstawowych warunków każdego badania naukowego" ${ }^{62}$. Nie zaniedbał również wymienić wszystkich 12 doktorów w zakresie historii średniowiecznej wypromowanych przez Handelsmana ${ }^{63}$ oraz trzech uczniów doprowadzonych do habilitacji przez S. Kętrzyńskiego ${ }^{64}$. Wydaje się, że wśród dokonań mediewistycznych Handelsmana cenił najbardziej jego traktowanie problemów historii Polski na tle dziejów powszechnych. Wśród nich zwłaszcza

\footnotetext{
62 A. Gieysztor, Posłowie, [w:] M. Handelsman, Średniowiecze, s. 371.

63 Tamże, s. 370.

64 Tenże, Stanisław Kętrzyński, [w:] Historycy warszawscy ostatnich dwóch stuleci, red. A. Gieysztor, J. Maternicki, H. Samsonowicz, Warszawa 1986, s. 226 n.
} 
uznanie - wbrew przekonaniom większości ówczesnych polskich badaczy - istnienia feudalizmu w Polsce, a to z powodu występowania również w średniowiecznej Polsce cech charakterystycznych dla feudalizmu, a mianowicie immunitetu, officium-beneficium i zależności osobistych wewnątrz rycerstwa ${ }^{65}$.

W drodze naukowej S. Kętrzyńskiego uwagi godna wydała się mu wspominana już jego genealogia naukowa. Syn Wojciecha Kętrzyńskiego dzieciństwo spędził w cieniu lwowskiego Ossolineum i we Lwowie rozpoczął drogę naukową pod opieką dwóch uczonych o całkowicie różnej metodyce badawczej: Ludwika Finkla i T. Wojciechowskiego, którego intuicjonizm poznawczy i dedukcjonizm badawczy podziwiał, lecz go nie naśladował. Doktorat o Kazimierzu Odnowicielu Kętrzyński obronił w 1899 r., mając za promotora koryfeusza szkoły krakowskiej S. Smolkę, po czym przeszedł śladem innego wielkiego historyka krakowskiego - Stanisława Krzyżanowskiego - do studiów nad dyplomatyką polską wieków średnich. Te dwa wątki badawcze - początki Polski piastowskiej i dyplomatyka polska do końca XV w., wraz $\mathrm{z}$ innymi naukami pomocniczymi, przeplatały się w jego dojrzałej twórczości. Nie trudno zauważyć, że zainteresowania te S. Kętrzyński przekazał swojemu uczniowi A. Gieysztorowi.

Zainteresowania metodologią historii A. Gieysztora są doskonale widoczne w recenzji zatytułowanej Sposoby rozumowania i postępowania historyków opublikowanej w t. I czasopisma „Historyka. Studia Metodologiczne” z dzieła historyków belgijskich pochodzącego z $1963 \mathrm{r}^{66} \mathrm{Z}$ recenzji tej wynika, że Gieysztor był najdalszy od przypisywania szczególnej rangi postępowaniu w ramach krytyki historycznej, a to z tego powodu, że dotyczy ona faktów jednostkowych ${ }^{67}$, a jego interesowały fakty powtarzalne i one właśnie stanowiły w jego mniemaniu właściwy przedmiot badań historyka. Nic zatem dziwnego, że największą uwagę poświęcił w tej recenzji artykułowi Pierre’a Lebruna o metodyce badań strukturalnych i kwantytatywnych. Można domniemywać, że podobnie jak ten badacz również Gieysztor uważał, że „nauka historii nie jest, podobnie jak inne nauki społeczne, nauką o szczegółowym, a przez to niepoznawalnym, lecz o powtarzalnym”. I dalej: „Historyczny sposób widzenia rzeczy ludzkich w sferze prawidłowości i powtarzalności polega na użytkowaniu pojęcia struktury, co daje możliwość zrozumienia ruchów, czyli zmian wewnątrz

65 Tenże, Postowie, [w:] M. Handelsman, Średniowiecze, s. 364.

${ }^{66}$ Tenże, Sposoby rozumowania i postępowania historyków, Historyka. Studia Metodologiczne 1 (1967), s. 147-152.

67 Tamże, s. 147. 
struktury..." ${ }^{68}$. Przy omawianiu kolejnego artykułu - mediewisty Jana Dhondta, znajdujemy taką opinię samego Gieysztora: „Od lat kilkudziesięciu powstaje jednak wszędzie nowa historia, pełna szacunku dla erudycji, ale domagająca się także wysiłku intelektualnego, innego rzędu kwestionariusza stawianego źródłom, wykrywania nie tylko swoistości, ale i prawidłowości zjawisk" ${ }^{69}$.

Podsumowując rozważania na temat stosunku A. Gieysztora do źródeł i źródłoznawstwa, można stwierdzić, że wykorzystywał do każdego z podejmowanych tematów najszerszy krąg źródeł, nie ograniczając się do źródeł pisanych, ale sięgając do źródeł sfragistycznych, ikonograficznych, architektonicznych, obiektów pochodzących z wykopalisk archeologicznych oraz pozostałości w języku i folklorze. Warto jeszcze dodać, że źródło historyczne traktował nie tylko jako przekaz informacji, ale czerpał radość z prawidłowego odczytania i obcowania z nim jako faktem historycznym, mającym często dla badacza wartość estetyczną i emocjonalną. Mimo że cechowało go zamiłowanie źródłoznawcze i mistrzowskie opanowanie nauk pomocniczych historii, w pracach A. Gieysztora znajdujemy traktowanie faktów szczegółowych jako cząstki większej całości umożliwiające poznanie struktur społecznych, idei i wzorców zachowań charakterystycznych dla danej epoki.

Nadesłany: 15 XI 2020

Nadesłany po poprawkach recenzyjnych: 4 VIII 2021

Zaakceptowany: 5 VIII 2021

Prof. dr hab. Maria Koczerska

e-mail:mkoczerska@gmail.com

\section{Résumé}

\section{Source - Source Studies - Method in the Research of Aleksander Gieysztor}

Already during his historical studies at the University of Warsaw, Aleksander Gieysztor consciously improved his research skills as a historian, placing emphasis on the auxiliary sciences of history. He completed a two-year internship at the Central Archives of Historical

68 Tamże, s. 148.

69 Tamże, s. 150. 
Records; he simultaneously studied art history, and immediately after graduation, he was sent by Marceli Handelsman and Stanisław Kętrzyński to the École des chartes in Paris. His doctoral dissertation concerns papal diplomatics, but his conclusions go back to the genesis of the eleventh-century Crusades. After the war, Aleksander Gieysztor joined forces with archaeologists to conduct research on the origins of the Polish state. In his studies on the reception of Christianity in Poland, Gieysztor used hagiographical sources and art monuments in equal measure. In his studies on the Slav mythology, based on the foundations of cultural anthropology, he made use of particularly varied sources, including folklore from all over Slavdom, which preserved many pagan rituals. Anything a historian can draw knowledge of the past from was as a historical source for Gieysztor.

Translated by Agnieszka Tokarczuk

\section{Bibliografia/Bibliography}

Aleksander Gieysztor. Człowiek i dzieło, red. M. Koczerska, P. Węcowski, Warszawa 2016

Andrulewicz H., Geneza Orła Białego jako herbu Królestwa Polskiego w roku 1295, Studia Źródłoznawcze 13 (1968), s. 1-26

Bibliografia prac Aleksandra Gieysztora za lata 1935-1975, zestawily M. Koczerska, E. Suchodolska, J. Zwolińska, [w:] Cultus et cognitio. Studia z dziejów średniowiecznej kultury, Warszawa 1976, s. 9-10

Chronologia polska, red. B. Włodarski, Warszawa 1957, reprint Warszawa 2007

Collingwood R.G., The Idea of History, Oxford 1946

Dworzaczek W., Genealogia, t. 1-2, Warszawa 1959

Erdmann C., Die Entstehung des Kreuzzugsgedanken, Stuttgart 1932

Gieysztor A., Drzwi Gnieźnieńskie jako wyraz polskiej świadomości narodowościowej w XII wieku, [w: ] Drzwi Gnieźnieńskie, red. M. Walicki, t. I, Wrocław 1956, s. $1-19$

Gieysztor A., Krajobraz międzyrzecza Pilicy i Wisty we wczesnym średniowieczu, [w: ] Studia sandomierskie. Materiaty do dziejów miasta Sandomierza i regionu sandomierskiego, red. T. Wąsowicz, J. Pazdur, [Warszawa] 1967, s. 11-37

Gieysztor A., List Arona biskupa krakowskiego: następna próba odgadnięcia tekstu, [w: Benedyktyńska praca. Studia historyczne ofiarowane o. Pawtowi Sczanieckiemu $w$ 80. rocznicę urodzin, red. J.A. Spież, Z. Wielgosz, Tyniec 1997, s. 45-48

Gieysztor A., Mitologia Stowian, Warszawa 1982

Gieysztor A., Mitologia Stowian, wyd. 3 zmienione i rozszerzone, wstęp K. Modze- 
lewski, posłowie L.P. Słupecki, oprac. na podst. rękopisu A. Pieniądz, Warszawa 2006

Gieysztor A., Na południe od Warszawy przed potowa XVIII w., [w: ] Dzieje Mokotowa, red. J. Kazimierski i in., Warszawa 1972, s. 17-35

Gieysztor A., Nauki dające poznawać źródła historyczne w Uniwersytecie Warszawskim, [w:] Tradycje i perspektywy nauk pomocniczych historii w Polsce, Materiały z sympozjum w Uniwersytecie Jagiellońskim z dnia 21-22 października 1993 profesorowi Zbigniewowi Perzanowskiemu przypisane, red. M. Rokosz, Kraków 1995, s. 29-33

Gieysztor A., „Non habemus caesarem nisi regem”. Korona zamknięta królów polskich w końcu XV wieku i w wieku XVI, [w:] Muzeum i twórca. Studia z historii sztuki $i$ kultury ku czci prof. dr S. Lorentza, Warszawa 1969, s. 277-292

Gieysztor A., O dziedzictwie kultury, red. D. Gawin i in., Warszawa 2000, s. 157-163 Gieysztor A., O napisach na Drzwiach Gnieźnieńskich, [w: ] Drzwi Gnieźnieńskie, red. M. Walicki, t. 2, Warszawa 1959, s. 415-420

Gieysztor A., Posłowie, [w: ] M. Handelsman, Średniowiecze polskie i powszechne. Wybór pism, Warszawa 1966, s. 351-371

Gieysztor A., Posłowie, [w: ] S. Kętrzyński, Polska X-XI w., Warszawa 1961, s. 693$-712$

Gieysztor A., Postowie, [w: ] S. Smolka, Mieszko Stary i jego wiek oraz Uwagi o pierwotnym ustroju społecznym Polski piastowskiej, do przedruku przygot. i posłowiem opatrzył A. Gieysztor, Warszawa 1959, s. 649-672

Gieysztor A., Pradzieje żoliborskie: od wczesnego średniowiecza do połowy XVIII wieku, [w:] Żoliborz wczoraj, dziś, jutro, Warszawa 1970, s. 9-24

Gieysztor A., Praga najstarsza (między X i XIVw.), [w: D Dieje Pragi, Warszawa 1970, s. 7-24

Gieysztor A., Problem karolińskiej reformy pisma, Archeologia 5 (1952-1953), s. $155-177$

Gieysztor A., Problematyka ideologiczna Drzwi Gnieźnieńskich, Kwartalnik Historyczny 62 (1955), s. 142-161

Gieysztor A., Rola gestu w ceremonii koronacyjnej w Polsce średniowiecznej, [w: ] tegoż, Władza, symbole i rytuały, red. P. Mrozowski, P. Tyszka, P. Węcowski, Warszawa 2016, s. 49-60

Gieysztor A., Rzymska studzienka ze św. Wojciechem z roku ok. 1000, [w: ] Sztuka i historia. Ksiega pamiątkowa ku czci profesora Michała Walickiego, Warszawa 1966, s. $22-29$ 
Gieysztor A., Sanctus et gloriosissimus martyr Christi Adalbertus: un état et une église missionaire aux alentours de l'an mille, [w: ] La conversione al cristianesimo nell'Europa dell'alto medioevo, Settimane di studio del Centro italiano di studi sull'alto medioevo, 16: Spoleto, 14-20 aprile 1966, Spoleto 1967, s. 611-647

Gieysztor A., Spektakl i liturgia - polska koronacja królewska, [w: Kultura elitarna a kultura masowa w Polsce późnego średniowiecza, red. B. Geremek, Wrocław 1978, s. 9-23

Gieysztor A., Sposoby rozumowania i postępowania historyków, Historyka. Studia Metodologiczne 1 (1967), s. 147-152

Gieysztor A., Stanisław Kętrzyński, [w:] Historycy warszawscy ostatnich dwóch stuleci, red. A. Gieysztor, J. Maternicki, H. Samsonowicz, Warszawa 1986, s. 218-228

Gieysztor A., Stanisław Smolka jako mediewista, [w:] Spór o historyczna szkołę krakowska, red. C. Bobińska, J. Wyrozumski, Kraków 1972, s. 95-118

Gieysztor A., Śródmieścia Warszawy dzieje starsze, [w: ] Dzieje Śródmieścia, red. J. Kazimierski i in., Warszawa 1975, s. 29-46

Gieysztor A., W Archiwum Głównym prawie przed pótwieczem, Miscellanea Historico-Archivistica 2 (1987), s. 184-191

Gieysztor A., Wiejscy poprzednicy Ochoty do połowy XVII w., [w: ] Dzieje Ochoty, red. J. Kazimierski i in., Warszawa 1973, s. 15-27

Gieysztor A., Wielka Wola a Warszawa średniowieczna, [w: ] Dzieje Woli, red. J. Kazimierski i in., Warszawa 1974, s. 19-28

Gieysztor A., Wtadza Karola Wielkiego w opinii wspótczesnej, Warszawa 1938

Gieysztor A., Władza, symbole i rytuały, red. P. Mrozowski, P. Tyszka, P. Węcowski, Warszawa 2016

Gieysztor A., Wstęp, [w:] T. Wojciechowski, Szkice historyczne XI wieku, przygotował do druku i wstępem poprzedził A. Gieysztor, Warszawa 1970, s. 5-23

Gieysztor A., Zabytek w oczach historyka, [w: ] Konserwator i zabytek. In memoriam Jerzego Remera, Warszawa 1991, s. 11-16; II wyd. wg komputerowego tekstu referatu z 1978 r. [w:] A. Gieysztor, O dziedzictwie kultury, red. D. Gawin i in., Warszawa 2000, s. 157-163

Gieysztor A., Zarys dziejów pisma łacińskiego, Warszawa 1973, reprint Warszawa 2009

Gieysztor A., Zarys nauk pomocniczych historii, 2 t., wyd. III, rozszerzone przy współudziale S. Herbsta, Warszawa 1948

Gieysztor A., Ze studiów nad geneza wypraw krzyżowych. Encyklika Sergiusza IV (1009-1012), Warszawa 1948 
Gieysztor A., Herbst S., Szwankowski E., Kształty Warszawy, Biuletyn Historii Sztuki i Kultury 9 (1947), s. 148-210

Gieysztor A., Płoski S., Powstanie Warszawskie, Warszawa 1981

Gumowski M., Haisig M., Mikucki S., Sfragistyka, Warszawa 1960

Jarocki R., Opowieść o Aleksandrze Gieysztorze, Warszawa 2001

Jarocki R., Zrozumieć innych (o Aleksandrze Gieysztorze), [w:] Widzieć jasno bez zachwytu, Warszawa 1982, s. 15-22

Kiersnowski R., Pieniądz kruszcowy w Polsce wczesnośredniowiecznej, Warszawa 1960 Kiersnowski R., Wspominajac Aleksandra Gieysztora: w „Millenium”, Przegląd Historyczny 91 (2000), z. 1, s. 61-67

Kuczyński S.M., Pieczęcie książąt mazowieckich, Wrocław 1978

Listy Aleksandra Gieysztora (wybór), wyd. P. Węcowski, [w: Aleksander Gieysztor. Człowiek i dzieło, red. M. Koczerska, P. Węcowski, Warszawa 2016, s. 349-583

Maleczyński K., Bielińska M., Gąsiorowski A., Dyplomatyka wieków średnich, Warszawa 1971

Nauka jako stużba. W 70-lecie urodzin i 50-lecie pracy naukowej prof. Aleksandra Gieysztora, wywiad przeprowadziła M. Koczerska, Kronika Warszawy 1985, 3/4, 63-64

Ordo coronandi regis Poloniae, wyd. S. Kutrzeba, Archiwum Komisji Historycznej AU, t. 11, Kraków 1919, s. 133-216

Powstanie Warszawskie. Rękopis Aleksandra Gieysztora. Gross Born listopad/grudzień 1944 r., Pultusk 2016

Rokosz M., O profesorze Gieysztorze - migawki wspomnień, [w: ] Aleksander Gieysztor. Człowiek i dzieło, red. M. Koczerska, P. Węcowski, Warszawa 2016, s. 279-287

Schramm P.E., Herrschaftszeichen und Staatssymbolik. Beiträge zur Geschichte vom dritten zum sechszehnten Jahrhundert, t. 1-3, Stuttgart 1955-1956

Semkowicz W., Paleografia łacińska, Kraków 1951, II wyd.: Kraków 2002 Semkowicz W., Ród Awdańców w wiekach średnich, Poznań 1920

Tyszkiewicz J., Z perspektywy lat, [w:] Aleksander Gieysztor. Człowiek i dzieło, red.

M. Koczerska, P. Węcowski, Warszawa 2016, s. 321-326

Wojciechowski T., Chrobacja. Rozbiór starożytności stowiańskich, t. 1, Kraków 1873 Wojciechowski T., Kościót katedralny w Krakowie, Kraków 1900 